\title{
sciendo
}

\section{Attitude toward innovativeness based on personality traits in the SME sector. Czech Republic case study}

\author{
Ludmila KOZUBÍKOVÁ \\ Tomas Bata University in Zlín, Faculty of Management and Economics, Zlín, Czech Republic \\ kozubikova@fame.utb.cz \\ Martin ČEPEL \\ Paneuropean University in Bratislava, Bratislava, Slovak Republic \\ Monika ZLÁMALOVÁ \\ Tomas Bata University in Zlín, Faculty of Management and Economics, Zlín, Czech Republic
}

\begin{abstract}
The research of personality characteristics of small and medium-sized enterprise (SME) entrepreneurs in relation to EO constructs is an important part of the research of the whole entrepreneurial environment of small and medium-sized enterprises. The aim of this paper is to search for a relationship between personality traits and the attitude toward innovativeness as a construct of EO of SME entrepreneurs in the Czech Republic based on their sociodemographic factors (gender, education, and age). Results from a questionnaire-based survey of the entrepreneurial environment of SME in the Czech Republic showed that the attitude toward innovativeness differed for entrepreneurs considering perseverance and responsibility to be important for entrepreneurship based on their education level. Entrepreneurs with secondary education or secondary educated with graduation were more confident about the reputation of their business as an innovator than university educated entrepreneurs.
\end{abstract}

Keywords: small and medium-sized enterprises, innovativeness, risk taking, proactiveness, entrepreneur's age, gender, education, Czech Republic.

Please cite the article as follows: Kozubíková, L., Čepel, M. and Zlámalová, M. (2018), “Attitude toward innovativeness based on personality traits in the SME sector. Czech Republic case study", Management \& Marketing. Challenges for the Knowledge Society, Vol. 13, No. 2, pp. 913-928, DOI: 10.2478/mmcks-2018-0013.

\section{Introduction}

The contemporary world is strongly affected by trends of globalization and competition in the marketplace. For these reasons, innovation is very important for every company. It has its consequences. The intensity of innovation activity can influence the competitiveness and consequently the business performance (Omerzel \& Jurdana, 2016). The authors considered intellectual capital as one of many factor of successful growth. They argue that the ability of a company to innovate depends on its ability to utilize its knowledge resources. (Omerzel \& Jurdana, 2016).

Entrepreneurs' innovativeness and personalities play a key role in the adoption of innovations in SMEs (Marcati, Guido \& Peludo, 2008).

Innovativeness as the ability to participate in innovation processes is a competence closely linked to participation processes in a dynamic, ever-changing society that needs mature citizens who shape the present and the future in accordance with their ideas, interests and social responsibility (Weis, Scharf \& Gryl, 2017). 
There is a wide range of literature dealing with the factors that determine firm innovation. This paper puts emphasis on the selected sociodemographic factors, namely gender and education of the entrepreneur and his age and on the selected personality characteristics of an entrepreneur considered to be important for entrepreneurship. There is little evidence of these relationships in the Czech Republic.

This paper contributes to the research field of entrepreneurship by providing novel empirical evidence on the relationship between personality traits and attitude toward firm innovation based on sociodemographic factors in the SME sector in the Czech Republic. The findings regarding this link allow to extend the understanding of the innovativeness as a construct of entrepreneurial orientation (EO).

This paper has the following structure: The theoretical part describes the essential attributes of the innovativeness in the context of EO, the role of personality traits of an entrepreneur, the influence of the selected sociodemographic factors (entrepreneur's age, gender, and education) on the perception of the innovativeness and other constructs of EO. The next section presents objectives, methodology, and resources used in the research. Finally, the most important results and recommendations for the theoretical area and the economic practice are stated.

\section{Literature review}

Small and medium-sized enterprises (SMEs) play a decisive role in job creation and are generally a factor of social stability and economic development. These enterprises often have difficulties obtaining capital or loans due to some financial markets' persistent reluctance to risk, and limited reinsurance which they can offer. Limited capital resources available for SMEs can also limit the attitude toward information, especially about new technologies and potential markets. All of these barriers can hinder SMEs in their development, including various forms of innovations (European Union Commission, 2014). Due to the features of SMEs, in this case especially their size, also administrative burden, corruption, and clientelism are perceived to be much worse in the SME sector in the Czech Republic compared to larger companies (see e.g. the results by Virglerová et al., 2016).

According to authors like Dobeš et al. (2017), Ključnikov et al. (2017a, 2017b), Mura et al. (2017) and Kozubíková et al. (2017), the development of SMEs is generally considered to be a main factor of economic development.

The importance of SMEs for the performance of the Czech economy is supported by the data on basic economic indicators in the period of 2010-2015 presented in the Report on development of SMEs and their support in 2015 (Ministry of Industry and Trade of the Czech Republic, 2016). The share of SMEs in the total number of active business entities in 2015 reached $99.83 \%$, the share of value added by SMEs in 2015 reached $54.12 \%$, and the share of employees of SMEs on the total number of employees in business area in the Czech Republic reached $58.9 \%$ in 2015.

For the purpose of this paper, innovativeness was considered as one construct of EO. It is possible to understand EO in various ways. According to Covin and Wales (2012), the concept of EO can be seen in two ways. The first concept is multidimensional and includes three dimensions of EO, specifically innovativeness, risk taking, and proactiveness. This concept of EO is based on the original concept by Miller (1983). The second attitude was defined by Lumpkin and Dess (1996) and it contains five constructs of EO. Lumpkin and Dess (1996) extended the concept of Miller (1983) by two other elements, precisely of 
competitive aggressiveness and autonomy. In this research, the concept of Lumpkin and Dess was adopted, with innovativeness being considered as one of the five elements of EO. Similarly, Lim and Envick (2013), Moss et al. (2015), and Lechner and Gudmundsson (2014) also used this five-dimensional concept of EO.

According to Moreno and Casillas (2008), innovativeness of companies can be defined as the intention to encourage new creative ideas, experiments, and processes (e.g. entrepreneurial networking, Machová et al. (2017), that may result in new products, services, or technological processes. It is possible to find other opinions on the role of innovativeness in the concept of EO by many authors (Boyer \& Blazy, 2014; ZorteaJohnston et al, 2012; Martínez-Román \& Romero, 2017).

The results of Boyer and Blazy (2014) showed that innovativeness is associated with personal characteristics of an entrepreneur, such as age, gender, professional experience, and also financial resources of a company.

Omerzel and Jurdana (2016) focused on the antecedents of innovation, such as the possession of adequate employee and management competencies, attitudes, good relationships within the workforce and with the environment, adequate organizational technology, etc. Their results show that intellectual capital (including human capital, social capital, and organizational capital in their concept) is an important element for the innovativeness and consequently for the company performance. They revealed that the social capital dimension is positively related to innovativeness (and growth). It can be understood that the more employees are collaborating with each other, sharing information, interacting, and exchanging ideas, the more innovative the firm will be (and will grow). The authors also search relationship between human capital and innovativeness (and growth). Their results show that the better structure of employees regarding the creative skills, expertness and capability of developing new ideas, the better the innovativeness (and grow) of the firm is. Furthermore, the more the firm uses different ways of storing knowledge, the more innovative the firm becomes and is able to grow.

Martínez-Román and Romero (2017) found that the entrepreneur's education plays an important role in innovativeness. According the authors there are two main determinants of innovativeness in SMEs: personal characteristics of the entrepreneur and the characteristics of the organization. This opinion, especially the role of entrepreneur's personal characteristics in innovativeness, supports the opinion of Boyer and Blazy (2014). Martínez-Román and Romero (2017) deal with this idea in more detail and state that the innovative behavior of SMEs is determined by personal characteristics of the owner and the main person responsible for decision making. Out of a number of personal characteristics, they stress the role of education in innovativeness. The same authors Romero and Martínez-Román (2012) have emphasized indirect influence of education through other personal features for example, in the entrepreneur's motivation and management style. Summarizing the previous opinions, it seems reasonable to consider the entrepreneur's educational level as the important influential characteristic of the innovative behavior of SMEs.

The issue of factors affecting the SMEs' innovative activity was further searched by authors Martínez-Román and Romero (2013; 2017). They revealed that the entrepreneur's motivation represents an important influential factor of innovativeness. Entrepreneurs with extrinsic motivations are less prone to innovation than those who are moved by intrinsic motivations. Besides motivation, authors state that leadership capacity and risk- 
taking represent other psychological features of entrepreneurs influencing innovative behavior. There were mentioned two levels of factors affecting innovativeness: the personal characteristics of the entrepreneurs (age, motivations, educational background, and degree of interpersonal trust) and the characteristics of the organizations' management cooperation, risk taking, proactivity, and specific innovation and growth policies in Martínez-Román and Romero (2013).

In terms of an entrepreneur's education, results have been revealed on the positive influence of education on individual EO and a firm's EO (Altinay \& Wang, 2011; Rauch \& Rijsdijk, 2013; Mengistae, 2006). The positive impact of the education on innovation was emphasized in studies by Mervel and Lumpkin (2007) who highlighted the positive influence on innovation radicalness, and also by De Winne and Sels (2010) who emphasized a significant influence of education on innovation output. The results by Olivari (2016) showed that entrepreneurs who attain high levels of education and are intrinsically motivated manage firms that are more likely to introduce innovations, although education seems to matter more than motivation. It suggests that any attempt to understand what makes firms go innovative needs to take into consideration the person behind the decisionmaking process: the entrepreneur.

In an SME entrepreneur's irreplaceable role of managing his/her company, the issue of "suitable" personality traits seems to be a frequently discussed topic in both theory and practice. Personal traits characterise the personality of the entrepreneur and include nonspecific general attributes, such as clear record, trustworthiness, honesty, fairness, adherence to principles, consistency, politeness, consideration, precision, and also some specific ones such as decisiveness, dutifulness, spirit of initiative, goal orientation, persistence, self-reliance, responsibility, diligence, and social skills (Veber et al., 2012).

Entrepreneurs should be capable of having the features of several personalities at once and as one person to demonstrate the ability to act as investors, inventors, accountants, dispute investigators, leaders, technologists, marketing specialists, and top sellers. Because of this, the more knowledge and skills the entrepreneur is capable of demonstrating, the better. The same authors discuss the question of optimism that is required for entrepreneurs to believe in the feasibility and success of an idea, but may have negative consequences because it can lead to overextension and flawed forecasts (Frese \& Gielnik, 2014).

The necessary personality characteristics are searched and discussed by many authors (Bruttel \& Fischbacher, 2013; Rampton, 2014; Hall, 2012; Pofeldt, 2014; Hines, 2004)

Bruttel and Fischbacher (2013) prefer entrepreneurs' traits such as efficiency, generosity, and they should not primarily seek to maximize their personal monetary benefit or to obtain a positive public image.

For comparison, Rampton (2014), Hall (2012), and Pofeldt (2014) consider the following traits to be the most important for an entrepreneur: passion, resilience, strong sense of self, flexibility, vision, courage/willingness to take risks, positive attitude, strength of character, integrity, ability to engender trust, dedication, creativity, leadership skills, tenacity, independence, and risk-taking.

Hines (2004) believes that there are at least 9 other characteristics (apart from general personal characteristics such as honesty, intelligence, good education in the chosen 
field) that he values highly: energy level, ego, courage, enthusiasm, and desire to make money, creativity, resourcefulness, tenacity, and leadership qualities.

Doris and Kusce (2013) take into account following traits: need for achievement, desire for independence, self-confidence, locus of control, risk taking propensity, knowledge and information, recognition and opportunity.

In an interesting study by Olivari (2016), it was discovered that entrepreneurial traits are important in explaining firm innovation propensity. It has its consequences. If we want to better explain firm innovation, we should also take into account the entrepreneur's personal characteristics.. Similarly as Martínez-Román and Romero (2013; 2017), Olivari (2016) consider that both entrepreneurial motivations and education are important for understanding a firm's tendency to innovate.

From the view of gender, studies show that there are many differences between male and female entrepreneurs. Goktan and Gupta (2015) revealed that men tend to be much more innovative, risk taking, and proactive in businesss than men. Ayub et al. (2013) are also convinced of higher innovativeness of male entrepreneurs. In comparison, other authors perceive female entrepreneurs as more innovative than their male counterparts (Diaz-Garcia \& Jimenez-Moreno, 2010; Runyan et al., 2006). On the other hand, Jelenc, Pisapia and Ivanusic (2015) found that there is no difference between men and women in the matter of innovativeness and risk taking.

Bernardino, Santos and Ribeiro (2018) suggest that both female and male social entrepreneurs have personalities characterized by high levels of openness to experience, agreeableness, conscientiousness, extraversion, and emotional stability.

Strohmeyer, Tonoyan and Jennings (2017) researched the issue of the influence of gender on firm's innovativeness. They revealed that overall, female-led firms tend to exhibit a lower breadth (the number of different domains, i.e. products, processes, marketing, and/or organizational) and depth of innovation (the frequency and radicalness of a firm's new offerings regardless of the domains in which they are introduced), although these differences are non-existent within certain domains (specifically marketing or organizational innovations) and within certain types of industries (specifically for innovation depth within less-innovative contexts).

In relation to the entrepreneur's age, Kraus (2013) states that more experienced entrepreneurs are more risk taking, innovative and proactive within their organization. The age is also examined in studies of Lévesque and Minniti (2006) or Kautonen, Down and Minniti (2014). These authors found that with the entrepreneur's increasing age, the opportunity costs of his/her time increase and therefore, his/her business activity declines. Olivari (2016) found out that the more business expertise entrepreneurs are able to better inform and gather relatively unrelated information related, and they might be able to identify more innovative opportunities. But overall, there is little evidence on the direct influence of an entrepreneur's age on the firm's innovativeness.

There is also broad evidence of different obstacles of innovation. For example Strobel and Kratzer (2017) found that the internal obstacles, lack of know-how, capacity overload, unclear roles and tasks, as well as the external obstacles such as governmental bureaucracy negatively influence the innovative performance of SMEs.

For comparison, Bigliardi and Galati (2016) identified four main barriers of innovativeness in Italian SMEs (knowledge, collaboration, organizational, and financial and strategic). 
Brancati (2015) emphasizes that financial frictions represent a severe obstacle to firm's innovativeness. Not only do SMEs have a lower probability to innovate and a higher likelihood to face financial constraints, their innovative propensity is also more sensitive to the firm's financial condition. They suggest that the establishment of close ties with the lender bank can help overcome financial barriers to innovation.

\section{Research methodology Research focus}

The aim of this paper is to search for relationship between personality traits and attitude toward innovativeness as a construct of EO of SME entrepreneurs in the Czech Republic based on their sociodemographic factors (gender, education, age). The results are based on data from the research of entrepreneurial environment of SMEs in the Czech Republic.

\section{Data handling}

The research of the business environment was conducted in the Czech Republic in 2015. The companies were chosen from the Albertina database and 1650 randomly selected firms in total were addressed by e-mail or phone to fill in the questionnaire at https://docs.google.com/forms/d/1U9coaC5JRL0N2Q0006Xb8j3mnaZXdSM47Kugt4EDGF $\mathrm{o} /$ viewform?usp=send_form. The data was provided by 1141 owners of SMEs in 14 regions of the Czech Republic. The questionnaire consisted of 52 questions. In the first nine questions, the structure of the respondents in relation to their education, gender, age, the residency and size of the firm, the length and area of conducting business, motives for starting a business, and the most important characteristics of an entrepreneur were analyzed. The rest of the questions were scale questions on a 1-5 scale (1 - strongly agree, 2 - agree, 3 - neutral, 4 - disagree, 5 - strongly disagree) focused on five elements of entrepreneurial orientation.

In accordance with the objectives, the innovativeness as a studied EO construct was examined through three questions (determinants of the EO constructs) in the questionnaire. Three determinants of EO for the construct innovativeness $\left(\mathrm{EO}_{11}-\right.$ The Reputation of a company as an innovator, $\mathrm{EO}_{12}$ - The development of new products and services in a company, $\mathrm{EO}_{13}$ - Investing in development of new methods and technologies) were examined. During the research, these three statements were used for the innovativeness to search the attitude of SME entrepreneurs toward this element of EO. One question of the questionnaire was aimed at selecting important personality traits for starting a business. Each respondent was to choose a maximum of three personality traits. For the purpose of this paper, those entrepreneurs of the whole sample of 1141 respondents were selected in three groups - the first group consisted of entrepreneurs who considered expertise to be important for starting a business, the second group consisted of entrepreneurs considering perseverance to be important, and the third group consisted of entrepreneurs considering responsibility to be important for starting a business. In the next step, each group was divided based on the entrepreneurs' age, gender, and education. The structure of the selected respondents who considered expertise, perseverance, and responsibility to be important for starting a business was as follows:

- the structure of the first group consisting of entrepreneurs considering expertise to be important for entrepreneurship was as follows: 619 entrepreneurs in total, 454 (74\%) men, 163 (26\%) women, 399 (64\%) secondary educated or secondary 
educated with graduation, 220 (36\%) university graduates, 292 (47\%) of the age of up to 45 years, 327 (53\%) of the age of more than 45 years;

- the structure of the second group consisting of entrepreneurs considering perseverance to be important for entrepreneurship was as follows: 583 entrepreneurs in total, $448(77 \%)$ men, $135(23 \%)$ women, 386 (66\%) secondary educated or secondary educated with graduation, 197 (34\%) university graduates, 324 (56\%) of the age of up to 45 years, 259 (44\%) of the age of more than 45 years;

- the structure of the third group of entrepreneurs considering responsibility to be important for entrepreneurship was as follows: 603 entrepreneurs in total, 448 (74\%) men, 155 (26\%) women, $402(67 \%)$ secondary educated or secondary educated with graduation, 201 (33\%) university graduates, 307 (51\%) of the age of up to 45 years, 296 (49\%) of the age of more than 45 years. Because of the fact that entrepreneurs were to choose three personality traits, the total number of entrepreneurs of all three groups was more than 1141.

To fulfill the main aim of searching for a relationship between personality traits and attitude toward innovativeness as a construct of EO of SME entrepreneurs in the Czech Republic based on their sociodemographic factors (gender, education, age), the test of the relevance of a difference between two average values for independent choices (two-choice un-pair t-test) was used. Students' t-test for independent optional samples tests the hypothesis about the difference of averages of two groups (the value of a binary variable determines pertinence to each group). The test is used for verifying the randomness of the difference calculated of the averages (if the difference is random, it equals 0 ; if the difference is statistically significant, it does not equal 0 ). The T-test is a suitable statistical method used for fulfilling a partial aim of the research. Due to the fact that entrepreneurs filled in the on-line questionnaire independently of each other and in different moments, the presumption necessary for realizing the t-test (the independence of the selected samples) is fulfilled.

For the realization of the t-test, it was necessary to do the following steps:

The entrepreneurs expressed their opinion of all indicators by selecting one of the qualitative possibilities: strongly agree, agree, neutral, disagree, strongly disagree;

- each qualitative statement regarding the five levels was evaluated using the Likert scale: strongly agree $($ score $=2)$, agree $($ score $=1)$, neutral (score $=0$ ), disagree (score $=1$ ), and strongly disagree (score $=-2$ );

- statistical instruments of descriptive statistics (tables, descriptive characteristics number of entrepreneurs in regards to the sociodemographic characteristic, sum of score, and average). Explanation: the score is calculated by the sum of all evaluations. Statistical methods of absolute number and simple ranking of statistical attribute and classifications according to two statistical attributes were applied;

- hypotheses were formulated and the two-choice un-pair t-test was used for finding out the difference of average values between the samples (if the result equals 0 , as opposed to the situation when the result does not equal 0);

- the significance level was set at 0,05 for all realized tests;

- t-test and its $\mathrm{p}$-value $(\mathrm{P}(\mathrm{T}<=\mathrm{t}))$ were calculated;

- a decision on accepting or rejecting a zero hypothesis was made (of the hypothesis formulated by the authors). 
The premises for conducting the normal distribution of data in the sample and the independence of samples were probed before conducting the t-test. To verify the assumption of normality, a graphic analysis of data was used (the comparison of histograms in the sample with a normal distribution curve), but also the Chí-square test of goodness-offit. For a better understanding and intelligibility, these results are not mentioned in this paper; however, it was confirmed that all conditions for conducting both two-choice tests (un-pair) were fulfilled. The conditions for conducting the t-tests and subsequent testing of statistical hypothesis were verified using sophisticated statistical software called SPSS Statistics.

Based on the literature review and taking into account the little evidence on this topic in the Czech Republic, the following statistical hypotheses for the purpose of this paper were stated:

H1: It can be assumed that there are no statistically significant differences in the perception of the innovativeness $\mathrm{EO}_{11}$ indicator in all three groups of entrepreneurs considering expertise, responsibility, and perseverance to be important for entrepreneurship based on their gender, age, and education.

H2: It can be assumed that there are statistically significant differences in the perception of the innovativeness $\mathrm{EO}_{12}$ indicator in the group of entrepreneurs considering expertise necessary for entrepreneurship.

H3: It can be assumed that there are no statistically significant differences in the perception of the innovativeness $\mathrm{EO}_{12}$ indicator in the group of entrepreneurs considering expertise to be important for entrepreneurship based on gender and age.

H4: There are statistically significant differences in the perception of the innovativeness $\mathrm{EO}_{12}$ indicator in the group of entrepreneurs considering perseverance to be important for entrepreneurship based on age, gender, and education.

H5: There are statistically significant differences in the perception of the innovativeness $\mathrm{EO}_{13}$ indicator in the group of entrepreneurs considering responsibility to be important for entrepreneurship based on gender, age, and education.

\section{Results and discussion}

There are results related to the first indicator of innovativeness that were used to search the attitude of SME entrepreneurs in the Czech republic toward innovativeness: $\mathrm{EO}_{11}-$ „My company has a reputation of an innovator" regarding the selected three groups of the whole sample of 1141 based on personality traits such as expertise, perseverance, and responsibility and in the second step according to selected sociodemographic factors in Table 1.

Table 1. The evaluation of the statement "My company has a reputation of an innovator" in regards to selected entrepreneurs' personality traits and sociodemographic factors

\begin{tabular}{|c|c|c|c|c|c|c|}
\hline \multicolumn{8}{|c|}{ Personality trait - Expertise } \\
\hline \multirow{2}{*}{ Characteristics } & \multicolumn{2}{|c|}{ Gender } & \multicolumn{2}{c|}{ Education } & \multicolumn{2}{c|}{ Age } \\
\cline { 2 - 7 } & Men & Women & OE & UE & $\mathbf{- 4 5}$ & $\mathbf{4 5 +}$ \\
\hline Number & 456 & 163 & 399 & 220 & 292 & 327 \\
\hline Score & 129 & 32 & 84 & 77 & 82 & 79 \\
\hline Mean & 0,2829 & 0,1963 & 0,2105 & 0,3500 & 0,2808 & 0,2416 \\
\hline t - Statistics & \multicolumn{2}{|c|}{0,765} & \multicolumn{3}{c|}{$-1,109$} & \multicolumn{2}{c|}{0,482} \\
\hline
\end{tabular}

Vol. 13, No. 2, Summer, pp. 913-928, ISSN 1842-0206| Management \& Marketing. Challenges for the Knowledge Society 


\begin{tabular}{|c|c|c|c|c|c|c|}
\hline $\mathrm{P}(\mathrm{T}<=\mathrm{t})$ & \multicolumn{2}{|c|}{0,311} & \multicolumn{2}{|c|}{0,199} & \multicolumn{2}{|c|}{0,787} \\
\hline \multicolumn{7}{|c|}{ Personality trait - Perseverance } \\
\hline \multirow{2}{*}{ Characteristics } & \multicolumn{2}{|c|}{ Gender } & \multicolumn{2}{|c|}{ Education } & \multicolumn{2}{|c|}{ Age } \\
\hline & Men & Women & OE & UE & -45 & $45+$ \\
\hline Number & 448 & 135 & 386 & 197 & 324 & 259 \\
\hline Score & 113 & 24 & -107 & -67 & 74 & 63 \\
\hline Mean & 0,2522 & 0,1778 & 0,1684 & 0,3655 & 0,2410 & 0,2432 \\
\hline $\mathrm{t}$ - Statistics & \multicolumn{2}{|c|}{0,646} & \multicolumn{2}{|c|}{$-1,811$} & \multicolumn{2}{|c|}{0,015} \\
\hline $\mathrm{P}(\mathrm{T}<=\mathrm{t})$ & \multicolumn{2}{|c|}{0,521} & \multicolumn{2}{|c|}{0,043} & \multicolumn{2}{|c|}{0,987} \\
\hline \multicolumn{7}{|c|}{ Personality trait - Responsibility } \\
\hline \multirow{2}{*}{ Characteristics } & \multicolumn{2}{|c|}{ Gender } & \multicolumn{2}{|c|}{ Education } & \multicolumn{2}{|c|}{ Age } \\
\hline & Men & Women & $\mathbf{O E}$ & UE & -45 & $45+$ \\
\hline Number & 448 & 155 & 402 & 201 & 307 & 296 \\
\hline Score & 106 & 11 & 31 & 86 & 59 & 58 \\
\hline Mean & 0,2366 & 0,0710 & 0,0771 & 0,4279 & 0,1921 & 0,1959 \\
\hline $\mathrm{t}$ - Statistics & \multicolumn{2}{|c|}{1,401} & \multicolumn{2}{|c|}{$-3,367$} & \multicolumn{2}{|c|}{0,021} \\
\hline $\mathrm{P}(\mathrm{T}<=\mathrm{t})$ & \multicolumn{2}{|c|}{0,061} & \multicolumn{2}{|c|}{0,007} & \multicolumn{2}{|c|}{0,959} \\
\hline
\end{tabular}

Explanation: HE - higher educated, OE - other educated (secondary school and high school with graduation), -45 - entrepreneurs up to 45 years, $45+$ - entrepreneurs older than 45 years.

Source: Authors' own research.

There are no statistically significant differences between sociodemographic factors (gender, age, and education) in the perception of the $\mathrm{EO}_{11}$ indicator - "My company has a reputation of an innovator" in the group of entrepreneurs who considered expertise to be important for entrepreneurship (gender: $\mathrm{P}(\mathrm{T}<=\mathrm{t})=0,311$; education: $\mathrm{P}(\mathrm{T}<=\mathrm{t})=0,199$; age: $\mathrm{P}(\mathrm{T}<=\mathrm{t})=0,787)$.

In the same group of entrepreneurs considering perseverance to be important for entrepreneurship, the research revealed statistically significant differences due to the education level in perception of the $\mathrm{EO}_{11}$ indicator (education: $\mathrm{P}(\mathrm{T}<=\mathrm{t})=0,043$ ).

Statistically significant differences were also found due to the education level in the group of entrepreneurs who considered responsibility to be important for business (education: $\mathrm{P}(\mathrm{T}<=\mathrm{t})=0,007$ ).

Overall, hypothesis $\mathrm{H} 1$ was not confirmed due to the results of t-test because in the groups of entrepreneurs considering perseverance and responsibility to be necessary for entrepreneurship, differences in attitude toward the $\mathrm{EO}_{11}$ were revealed.

Table 2 presents results on the second indicator $\mathrm{EO}_{12}$ - „We regularly develop new products and services in my company" of the innovativeness construct in relation to the personality traits and selected sociodemographic factors.

Table 2. The evaluation of the statement "We regularly develop new products and services" in regards to selected entrepreneurs' personality traits and sociodemographic factors

\begin{tabular}{|c|c|c|c|c|c|c|}
\hline \multicolumn{8}{|c|}{ Personality trait - Expertise } \\
\hline \multirow{2}{*}{ Characteristics } & \multicolumn{2}{|c|}{ Gender } & \multicolumn{2}{c|}{ Education } & \multicolumn{2}{c|}{ Age } \\
\cline { 2 - 7 } & Men & Women & OE & UE & $\mathbf{- 4 5}$ & $\mathbf{4 5 +}$ \\
\hline Number & 456 & 163 & 399 & 220 & 292 & 327 \\
\hline Score & 214 & 96 & 191 & 119 & 152 & 158 \\
\hline Mean & 0,4693 & 0,5890 & 0,4787 & 0,5410 & 0,5205 & 0,4832 \\
\hline
\end{tabular}




\begin{tabular}{|c|c|c|c|c|c|c|}
\hline $\mathrm{t}$ - Statistics & \multicolumn{2}{|c|}{$-0,902$} & \multicolumn{2}{|c|}{$-0,527$} & \multicolumn{2}{|c|}{0,492} \\
\hline $\mathrm{P}(\mathrm{T}<=\mathrm{t})$ & \multicolumn{2}{|c|}{0,297} & \multicolumn{2}{|c|}{0,698} & \multicolumn{2}{|c|}{0,705} \\
\hline \multicolumn{7}{|c|}{ Personality trait - Perseverance } \\
\hline \multirow{2}{*}{ Characteristics } & \multicolumn{2}{|c|}{ Gender } & \multicolumn{2}{|c|}{ Education } & \multicolumn{2}{|c|}{ Age } \\
\hline & Men & Women & OE & UE & -45 & $45+$ \\
\hline Number & 448 & 135 & 386 & 197 & 324 & 259 \\
\hline Score & 217 & 65 & 188 & 94 & 167 & 115 \\
\hline Mean & 0,4844 & 0,4815 & 0,4870 & 0,4772 & 0,5154 & 0,4440 \\
\hline $\mathrm{t}$ - Statistics & \multicolumn{2}{|c|}{0,031} & \multicolumn{2}{|c|}{0,087} & \multicolumn{2}{|c|}{0,654} \\
\hline $\mathrm{P}(\mathrm{T}<=\mathrm{t})$ & \multicolumn{2}{|c|}{0,995} & \multicolumn{2}{|c|}{0,977} & \multicolumn{2}{|c|}{0,443} \\
\hline \multicolumn{7}{|c|}{ Personality trait - Responsibility } \\
\hline \multirow{2}{*}{ Characteristics } & \multicolumn{2}{|c|}{ Gender } & \multicolumn{2}{|c|}{ Education } & \multicolumn{2}{|c|}{ Age } \\
\hline & Men & Women & $\mathbf{O E}$ & UE & -45 & $45+$ \\
\hline Number & 448 & 155 & 402 & 201 & 307 & 296 \\
\hline Score & 212 & 78 & 179 & 111 & 148 & 142 \\
\hline Mean & 0,4732 & 0,5032 & 0,4453 & 0,5522 & 0,4821 & 0,4797 \\
\hline $\mathrm{t}$ - Statistics & \multicolumn{2}{|c|}{$-0,415$} & \multicolumn{2}{|c|}{0,849} & \multicolumn{2}{|c|}{0,05} \\
\hline $\mathrm{P}(\mathrm{T}<=\mathrm{t})$ & \multicolumn{2}{|c|}{0,761} & \multicolumn{2}{|c|}{0,358} & \multicolumn{2}{|c|}{0,998} \\
\hline
\end{tabular}

Explanation: HE - higher educated, OE - other educated (secondary school and high school with graduation), -45 - entrepreneurs up to 45 years, $45+$ - entrepreneurs older than 45 years.

Source: Authors' own research.

Based on the results in Table 2, no statistically significant differences were revealed in perception of the $\mathrm{EO}_{12}$ indicator - „We regularly develop new products and services“ regarding sociodemographic factors (gender, age, and education) in the group of entrepreneurs who considered expertise, perseverance, and responsibility to be important for entrepreneurship (personality trait expertise for gender: $\mathrm{P}(\mathrm{T}<=\mathrm{t})=0,297$; education: $\mathrm{P}(\mathrm{T}<=\mathrm{t})=0,698$; age: $\mathrm{P}(\mathrm{T}<=\mathrm{t})=0,705$; for perseverance gender: $\mathrm{P}(\mathrm{T}<=\mathrm{t})=0,995$; education: $\mathrm{P}(\mathrm{T}<=\mathrm{t})=0,977$; age: $\mathrm{P}(\mathrm{T}<=\mathrm{t})=0,443$; for responsibility gender: $\mathrm{P}(\mathrm{T}<=\mathrm{t})=0,761$; education: $\mathrm{P}(\mathrm{T}<=\mathrm{t})=0,358$; age: $\mathrm{P}(\mathrm{T}<=\mathrm{t})=0,998)$. Summarizing the results of the tests used, hypotheses $\mathrm{H} 2$ and $\mathrm{H} 4$ were rejected and hypothesis $\mathrm{H} 3$ was confirmed.

Table 3 presents results on the third indicator $\mathrm{EO}_{13}$ - "We invest a lot of money in the development of new methods and technologies" of the innovativeness construct in relation to the personality traits and selected sociodemographic factors of entrepreneurs.

Table 3. The evaluation of the statement "We invest a lot of money in the development of new methods and technologies" in regards to selected entrepreneurs' personality traits and sociodemographic factors

\begin{tabular}{|c|c|c|c|c|c|c|}
\hline \multicolumn{7}{|c|}{ Personality trait - Expertise } \\
\hline \multirow{2}{*}{ Characteristics } & \multicolumn{2}{|c|}{ Gender } & \multicolumn{2}{|c|}{ Education } & \multicolumn{2}{|c|}{ Age } \\
\hline & Men & Women & OE & UE & -45 & $45+$ \\
\hline Number & 456 & 163 & 399 & 220 & 292 & 327 \\
\hline Score & 29 & 5 & 13 & 21 & 23 & 11 \\
\hline Mean & 0,0636 & 0,0307 & 0,0326 & 0,0955 & 0,0787 & 0,0336 \\
\hline t - Statistics & \multicolumn{2}{|c|}{0,322} & \multicolumn{2}{|c|}{$-0,639$} & \multicolumn{2}{|c|}{0,550} \\
\hline $\mathrm{P}(\mathrm{T}<=\mathrm{t})$ & \multicolumn{2}{|c|}{0,781} & \multicolumn{2}{|c|}{0,682} & \multicolumn{2}{|c|}{0,648} \\
\hline \multicolumn{7}{|c|}{ Personality trait - Perseverance } \\
\hline Characteristics & \multicolumn{2}{|c|}{ Gender } & \multicolumn{2}{|c|}{ Education } & \multicolumn{2}{|c|}{ Age } \\
\hline
\end{tabular}




\begin{tabular}{|c|c|c|c|c|c|c|}
\hline & Men & Women & OE & UE & -45 & $45+$ \\
\hline Number & 448 & 135 & 386 & 197 & 324 & 259 \\
\hline Score & 2 & 2 & -1 & 5 & 8 & -4 \\
\hline Mean & 0,0045 & 0,0148 & $-0,0026$ & 0,0254 & 0,0247 & $-0,0154$ \\
\hline $\mathrm{t}$ - Statistics & \multicolumn{2}{|c|}{$-0,07$} & \multicolumn{2}{|c|}{$-0,323$} & \multicolumn{2}{|c|}{0,509} \\
\hline $\mathrm{P}(\mathrm{T}<=\mathrm{t})$ & \multicolumn{2}{|c|}{0,956} & \multicolumn{2}{|c|}{0,774} & \multicolumn{2}{|c|}{0,702} \\
\hline \multicolumn{7}{|c|}{ Personality trait - Responsibility } \\
\hline \multirow{2}{*}{ Characteristics } & \multicolumn{2}{|c|}{ Gender } & \multicolumn{2}{|c|}{ Education } & \multicolumn{2}{|c|}{ Age } \\
\hline & Men & Women & $\mathbf{O E}$ & UE & -45 & $45+$ \\
\hline Number & 448 & 155 & 402 & 201 & 307 & 296 \\
\hline Score & -3 & -13 & -28 & 12 & -5 & -11 \\
\hline Mean & $-0,0067$ & $-0,0838$ & $-0,0697$ & 0,0597 & $-0,0163$ & $-0,0372$ \\
\hline $\mathrm{t}-$ Statistics & \multicolumn{2}{|c|}{0,657} & \multicolumn{2}{|c|}{$-0,964$} & \multicolumn{2}{|c|}{0,306} \\
\hline $\mathrm{P}(\mathrm{T}<=\mathrm{t})$ & \multicolumn{2}{|c|}{0,584} & \multicolumn{2}{|c|}{0,245} & \multicolumn{2}{|c|}{0,711} \\
\hline
\end{tabular}

Explanation: HE - higher educated, OE - other educated (secondary school and high school with graduation), - 45 - entrepreneurs up to 45 years, $45+$ - entrepreneurs older than 45 years.

Source: Authors' own research.

Due to the personality traits (in all three groups of entrepreneurs) and selected sociodemographic factors, no statistically significant differences were found in the perception of the $\mathrm{EO}_{13}$ indicator - „We invest a lot of money in the development of new methods and technologies". It can be explained that the entrepreneurs who consider expertise to be important for entrepreneurship have a similar attitude toward financing innovations as the entrepreneurs who consider perseverance or responsibility as important personality traits for an entrepreneur (personality trait expertise for gender: $\mathrm{P}(\mathrm{T}<=\mathrm{t})=$ 0,781; education: $\mathrm{P}(\mathrm{T}<=\mathrm{t})=0$,682; age: $\mathrm{P}(\mathrm{T}<=\mathrm{t})=0,648$; for perseverance gender: $\mathrm{P}(\mathrm{T}<=\mathrm{t})=$ 0,956; education: $\mathrm{P}(\mathrm{T}<=\mathrm{t})=0,774$; age: $\mathrm{P}(\mathrm{T}<=\mathrm{t})=0,702$; for responsibility gender: $\mathrm{P}(\mathrm{T}<=\mathrm{t})$ $=0,584$; education: $\mathrm{P}(\mathrm{T}<=\mathrm{t})=0,245$; age: $\mathrm{P}(\mathrm{T}<=\mathrm{t})=0,711)$. Based on the results of $\mathrm{t}$-test, $\mathrm{H} 5$ was rejected.

SMEs have a collectively high impact on the natural environment, as they represent more than $95 \%$ of private sector companies in most industrialized countries (Richert, 2017).

Understanding the psychological nature and development of the individual entrepreneur is at the core of contemporary entrepreneurship research. It is therefore important to understand this individual if one wants to have a better understanding of the entrepreneurial process and related topics such as entrepreneurial success or failure, entrepreneurship education, and entrepreneurial culture (Obschonka \& Stuetzer, 2017).

SMEs are aware of the necessity to realize innovations in sense of improvement of utility properties of products and technologies used in these processes. To achieve this goal SMEs are aware of the important role of knowledge in innovations. (Scuotto, Del Giudice \& Carayannis, 2017). These findings on the importance of innovativeness together with findings of other authors (Martínez-Román \& Romero, 2017; 2012; Boyer \& Blazy, 2014; Strohmeyer et al., 2017) confirm its irreplaceable role in the entrepreneurial orientation of not only SMEs.

Solving the issue of innovativeness in SMEs regarding the important personality traits and selected sociodemographic factors of an entrepreneur, it can be assumed that entrepreneurs considering expertise to be important for entrepreneurship differed in the 
attitude toward innovativeness in relation to education. It was assumed that university educated entrepreneurs were much more aware of the important role of innovations because of their knowledge gained at university in comparison with the entrepreneurs with secondary education.

The results partially confirmed the findings by Martínez-Román and Romero (2017) and also of Martínez-Román and Romero (2012); Mervel and Lumpkin (2007); De Winne and Sels (2010), and Olivari (2016) of the important influence of entrepreneurial education on innovativeness. On the other hand, these results did not confirm their findings and findings of Boyer and Blazy (2014) enhancing the importance of personality characteristics in innovativeness because little statistically significant differences were revealed regarding the selected personality traits.

Gender did not play any differentiating role in any of the evaluated innovative statement. Based on this fact, findings by Jelenc et al. (2015) can be confirmed, but not those by Runyan et al. (2006) or Diaz-Garcia and Jimenez-Moreno (2010) presuming that female entrepreneurs are more innovative than their male counterparts. Findings by Goktan and Gupta (2015) and Ayub et al. (2013) supposing bigger innovativeness of men in comparison with women cannot be confirmed either.

As mentioned above, no statistically significant differences were revealed between the younger (less than 45 years) and older entrepreneurs (more than 45 years). It implies that the age of the entrepreneur does not yield a different attitude toward innovativeness; neither does it take into account the different personality traits. Considering that the older an entrepreneur gets, the more experienced he/she is, the results by Kraus (2013) or Olivari (2016) cannot be confirmed, respecting the findings about no differentiating role of the age in connection to the attitude toward innovativeness. However, with respect to the age in relation to innovativeness, little evidence was found on this topic. A comparison with results of a previous research shows that age played a differentiating role in the attitude toward risk taking (Kozubíková et al., 2017b).

As for the personality traits that were taken into account, it was discovered that these traits (perseverance, expertise, and responsibility) do not cause differences in the attitude toward innovativeness. Considering the personality traits, it can be agreed with Olivari (2016) that when explaining the innovativeness, it is necessary to take into account the personality traits. The fact that no differentiating role was revealed despite a single case of perseverance and responsibility can be connected with the fact that the selected traits (perseverance, responsibility, and expertise) are considered to be important for entrepreneurship by most authors (Hines, 2004). On the other hand, differences found for perseverance regarding education do not correspond with the stated presumption. It was presumed that the higher the entrepreneur's education level, the higher his perseverance. Comparing the results of this research on the risk taking as a personality trait, education did not play a differentiating role in managing credit risk (see Belas et al., 2015).

\section{Conclusions}


The aim of this paper was to search for a relationship between personality traits and attitude toward innovativeness as a construct of EO of SME entrepreneurs in the Czech Republic based on their sociodemographic factors (gender, education, and age).

The most important findings of this paper showed that based on personality traits and sociodemographic factors, the researched entrepreneurs have a predominantly similar attitude toward innovativeness because no statistically significant differences were revealed due to the entrepreneurs' gender and age. It means that both male and female entrepreneurs, as well as entrepreneurs older (more than 45 years) and younger (less than 45 years) evaluated defined indicators of innovativeness in the same or similar way. The factor causing statistically significant differences was the factor of education for the entrepreneurs who considered perseverance and responsibility to be important for entrepreneurship. Other educated entrepreneurs were more confident about the reputation of their business as an innovator than university educated entrepreneurs in the group of entrepreneurs considering perseverance and responsibility to be important traits for entrepreneurs.

The novelty of this study lies in bringing findings in relationship to the attitude toward innovativeness and personality traits regarding the sociodemographic factors in the sample of Czech SME entrepreneurs because there is little evidence on this topic in the Czech Republic. The results found could have implications for decision makers in higher education institutions in terms of effective decision making process of entrepreneurship education.

There are certain limits to this research such as regional character of this study, limited possibilities of generalization, and lack of previous findings on this topic in the Czech Republic. Despite these limits, it is believed that this paper has brought interesting findings and new incentives for further research due to the important role of entrepreneurs' personality traits, especially in the SME sector.

\section{Acknowledgement}

The authors would like to thank the Internal Grant Agency of FaME for providing financial support to carry out this research. Funding was extended through TBU No. IGA/FaME/2017/007 - Financial and nonfinancial factors of credit risk of small and medium-sized enterprises in the Czech Republic.

\section{References}

Altinay, L., Wang, C. L. (2011), “The influence of an entrepreneur's socio-cultural characteristics on the entrepreneurial orientation of small firms", Journal of Small Business and Enterprise Development, Vol. 18, No. 4, pp. 673-694.

Ayub, A., Razzaq, A., Aslam, M. S., Iftekhar, H. (2013), "Gender effects on entrepreneurial orientation and value innovation: evidence from Pakistan", European Journal of Business and Social Sciences, Vol. 2, No. 1, pp. 82-90.

Belas., J., Kljucnikov, A., Vojtovic, S., Sobekova-Majkova, M. (2015), “Approach of the SME Entrepreneurs to Financial Risk Management in Relation to Gender and Level of Education", Economics and Sociology, Vol. 8, No. 4, pp. 32-42. 
Bernardino, S., Santos, J. F., Ribeiro, J. C. (2018), “Social entrepreneur and gender: what's personality got to do with it?", International journal of gender and entrepreneurship, Vol. 10, No. 1, pp. 61-82.

Bigliardi, B., Galati, F. (2016), "Which factors hinder the adoption of open innovation in SMEs?", Technology Analysis \& Strategic Management, Vol. 8, No. 1, pp. 869-885.

Boyer, T., Blazy, R. (2014), "Born to be alive? The survival of innovative and non-innovative French micro-start-up", Small Business Economics, Vol. 42, pp. 669-683.

Brancati, E. (2015), "Innovation financing and the role of relationship lending for SMEs", Small Business Economics, Vol. 44, No. 2, pp. 449-473.

Covin, J. G., Wales, G. (2012), "The measurement of entrepreneurial orientation", Entrepreneurship Theory and Practice, Vol. 36., No. 4, pp. 677-702.

De Winne, S., Sels, L. (2010), "Interrelationships between human capital, HRM and innovation in Belgian start-ups aiming at an innovation strategy", International Journal of Human Resource Management, Vol. 21, pp. 1863-1883.

Diaz-Garcia, M. C. and Jimenez-Moreno, J. (2010), „Entrepreneurial intention: the role of gender”, International Entrepreneurship Management Journal, Vol. 6, pp. 261-283.

Dobeš, K., Kot, S., Kramoliš, J., Sopková, G. (2017), “The Perception of Governmental Support in the Context of Competitiveness of SMEs in the Czech Republic", Journal of Competitiveness, Vol. 9, No. 3, pp. 34-50.

Doris, O. G., \& Kusce, I. (2013), "The influence of personal and environmental factors on etrepreneurs' performance", Kybernetes, Vol. 42, No. 6, pp. 906-927.

EU Commission (2014), "Regulation of EU Commission no 651/2014".

Frese, M., Gielnik, M. M. (2014). The Psychology of Entrepreneurship. Annual Review of Organizational Psychology and Organizational Behavior, 1, 413-438. doi: http://dx.doi.org/10.1146/annurev-orgpsych-031413-091326

Goktan, A. B., Gupta, V. K. (2015), „Sex, gender, and individual entrepreneurial orientation: evidence from four countries", International Entrepreneurship and Management Journal, Vol. 11, pp. 95-112.

Hines, J. L. (2004), “Characteristics of an entrepreneur”, Surgical Neurology, Vol. 61, No 4, pp. 407-408.

Jelenc, L., Pisapia, J., Ivanusic, N. (2015), “Demographic Variables Influencing Individual Entrepreneurial Orientation and Strategic Thinking Capability", 10 ${ }^{\text {th }}$ International Scientific Conference on Economic and Social Development, Miami.

Kautonen, T., Down, S., Minniti, M. (2014), „Ageing and entrepreneurial preferences”, Small Bus Econ, Vol. 42, pp. 579-594.

Ključnikov, A., Kozubíková, L., Sopková, G. (2017a), “The Payment Discipline of Small and Medium-sized Enterprises", Journal of Competitiveness, Vol. 9, No. 2, pp. 45-61.

Ključnikov, A., Popesko, B. (2017b), "Export and its Financing in the SME Segment. Case Study from Slovakia", Journal of Competitiveness, Vol. 9, No. 1, pp. 20-35.

Kozubíková, L., Homolka, L., Kristalas, D. (2017a), "The Effect of Business Environment and Entrepreneurs' Gender on Perception of Financial Risk in the SMEs Sector", Journal of Competitiveness, Vol. 9, No. 1, pp. 36-50.

Kozubíková, L., Dvorský, J., Cepel, M., Balcerzak, A. P. (2017b), “Important characteristics of an entrepreneur in relation to risk taking: Czech Republic case study", Journal of International Studies, Vol. 10, No. 3, pp. 220-233. 
Kraus, S. (2013), "The role of entrepreneurial orientation in service firms: empirical evidence from Austria", The Service Industries Journal, Vol. 33, No. 5, pp. 472-444.

Lechner, Ch., Gudmundsson, S. V. (2014), "Entrepreneurial orientation, firm strategy and small firm performance", International Small Business Journal: Researching Entrepreneurship, Vol. 32, No. 1, pp. 36-60.

Lévesque, M., Minniti, M. (2006), "The effect of ageing on entrepreneurial behavior", Journal of Business Venturing, Vol. 21, No. 2, pp. 177-194.

Lim, S., Envick, B. R. (2013), "Gender and entrepreneurial orientation: a multi-country study", Int Entrep Manag J, Vol. 9, pp. 465-482.

Lumpkin, G. T., Dess, G. G. (1996), „Clarifying the entrepreneurial orientation construct and linking it to performance", Academy of Management Review, Vol. 21, No. 1, pp. 135172.

Machová, R., Mura, L., Havierniková, K., Tóth, Zs. 2017. “The entrepreneur's network as a cooperation form of entrepreneurship: Case of Slovakia", Journal of Applied Economic Sciences, Vol. 12, No. 1, pp. 160-169.

Marcati, A., Guido, G., Peluso, A. M. (2008), "The role of SME entrepreneurs' innovativeness and personality in the adoption of innovations", Research Policy, Vol. 37, No. 9, pp. 1579-1590.

Martínez-Román, J. A., Romero, I. (2017), "Determinants of innovativeness in SMEs: disentangling core innovation and technology adoption capabilities", Review of Managerial Science, Vol. 11, No. 3, pp. 543-569.

Martínez-Román, J. A., Romero, I. (2013), "About the determinants of the degree of novelty in small businesses' product innovations", International Entrepreneurship and Management Journal, Vol. 9, No. 4, pp. 655-677.

Mengistae, T. (2006), "Competition and entrepreneurs, human capital in small business longevity and growth", Journal of Development Studies, Vol. 42, No. 5, pp. 812-836.

Mervel, M. R., Lumpkin, G. T. (2007), “Technology entrepreneurs' human capital and its effect on innovation radicalness", Enterprise Theory and Practice, pp. 807-828.

Miller, D. (1983), “The correlates of entrepreneurship in three types of firms", Management Science, Vol. 29, No. 7, pp. 770-791.

Ministry of Industry and Trade of the Czech Republic (2016), "Report on development of small and medium-sized enterprises and their support in 2015", Praha: MPO ČR.

Ministry of Industry and Trade of the Czech Republic (2015), "Report on development of small and medium-sized enterprises and their support in 2014", Praha: MPO ČR.

Moreno, N. M., Casillas, J. C. (2008), "Entrepreneurial orientation and growth of SMEs: a casual model. Entrepreneurship Theory and Practice, Vol. 32, No. 3, pp. 507-528.

Moss, T. W., Neubaum, D. O., Meyskens, M. (2015), „The Effect of Virtuous and Entrepreneurial Orientations on Microfinance Lending and Repayment: A Signaling Theory Perspective", Entrepreneurship Theory and Practice, Vol. 39, No. 1, pp. 2752.

Mura, L., Havierniková, K, Machová, R. (2017). “Empirical results of entrepreneurs' network: Case study of Slovakia", Serbian Journal of Management, Vol. 12, No. 1, pp. 121-131.

Obschonka, M., Stuetzer, M. (2017), “Integrating psychological approaches to entrepreneurship: The Entrepreneurial Personality System", Small Business Economics, Vol. 49, No. 1, pp. 203-231. 
Olivari, J. (2016), "Entrepreneurial traits and firm innovation”, Eurasian Business Review, Vol. 6, No. 3, pp. 339-360.

Omerzel, D. G., Jurdana, D. S. (2016), "The influence of intellectual capital on innovativeness and growth in tourism SMEs: empirical evidence from Slovenia and Croatia", Economic Research-Ekonomska Istraživanja, Vol. 29, No. 1, pp. 1075-1090.

Rauch, A., Rijsdijk, S. A. (2013), "The effects of general and specific human capital on longterm growth and failure of newly founded businesses", Entrepreneurship Theory and Practice, Vol. 37, No. 4, pp. 923-941.

Richert, M. (2017), “An energy management framework tailor-made for SMEs: Case study of a German car company”, Journal of Cleaner Production, Vol. 164, pp. 221-229.

Romero I, Martínez-Román, J. A. (2012), "Self-employment and innovation. Exploring the determinants of innovative behavior in small businesses", Res Policy, Vol. 41, No. 1, pp. $178-189$.

Runyan, C. R., Huddleston, P., Swinney, J. (2006), “Entrepreneurial orientation and social capital as small firm strategies: a case study of gender differences from resourcesbased view", Entrepreneurship Management, Vol. 2, pp. 455-477.

Scuotto, V., Del Giudice, M., Carayannis, E. G. (2017), "The effect of social networking sites and absorptive capacity on SMES' innovation", Journal of Technology Transfer, 42(2), 409-424. doi: http://dx.doi.org/10.1007/s10961-016-9517-0

Strobel, N., Kratzer, J. (2017), “Obstacles to innovation for SMEs: Evidence from Germany”, Int. J. Innov. Mgt., Vol. 21, No 3.

Strohmeyer, R., Tonoyan, V., Jennings, J. E. (2017), “Jacks-(and Jills)-of-all-trades: On whether, how and why gender influences firm innovativeness", Journal of Business Venturing, Vol. 32, No. 5, pp. 498-518.

Veber, J., Srpová, J. a kolektiv, „Podnikání malé a střední firmy”, 3. vyd. Praha: Grada, 2012. 336 s. ISBN 978-80-247-4520-6.

Virglerová, Z., Dobes, K., Vojtovic, S. (2016), “The Perception of the States Influence on its Business Environment in the SMEs from Czech Republic", Administratie si Management Public, Vol. 14, No. 26, pp. 78-96.

Weis, S., Scharf, C., Gryl, I. (2017), „New and even newer fostering innovativeness in primary education", $4^{\text {th }}$ International Conference on Education and Social Sciences (INTCESS 2017), Instanbul, Turkey, $6^{\text {th }}-8^{\text {th }}$ February.

Zortea-Johnston, E., Darroch, J., Matear, S. (2012), "Business orientation and innovation in small medium sized enterprises", International entrepreneurship Management Journal, Vol. 8, pp. 145-164. 